\title{
New Product Development and Consumer Brand Adoption in SMEs Manufacturing Industry in Ogun State Nigeria Kesinro $\mathrm{OR}^{1 *}$, Adenugba $\mathrm{AA}^{2}$ and Ademilua $\mathrm{AV}^{2}$
}

${ }^{1}$ Department of Administration and Management, Crawford University, Igbesa, Ogun State, Nigeria

${ }^{2}$ Department of Accounting and Finance, Crawford University, Igbesa, Ogun State, Nigeria

\begin{abstract}
The study examines the effect of New Product Development strategies on Consumer Brand Adoptionin SMEs in the manufacturing industry in Ogun State, Nigeria. The main objective of the study is to determine the relationships between brand physical attributes, buyer behaviour, market pre-testing strategy, product adoption, marketing planning policy and competitive edge of SMEs products in Ado-odo/Ota Local Government Area of Ogun State, Nigeria. The research design is the descriptive survey and data were gathered through a well-structured questionnaire rated on a 6-point Likert scale of Strongly Agree to Strongly Disagree. The population of the study comprised 240 ownermanagers and employees of selected companies presumed to host most of the SMEs in the state. The simple random sampling technique was used to select a sample of 150 individuals. 134 copies of the questionnaire were returned and analyzed using the percentile and simple regression statistical techniques. The study reveals that physical attributes of SMEs products have significant weak relationship with buyer behaviour $(R=0.333 ; p<0.05)$; there is significant moderate relationship between market pre-testing strategy and adoption of product $(R=0.342$; $p<0.05)$ and there is significant but weak relationship between marketing planning policy and improve competitive edge of SMEs products $(R=0.125, p<0.05)$. The study recommends that small businesses periodically review the techniques employed in product development to enhance brand image and consumer expectation that guarantee consumer loyalty.
\end{abstract}

Keywords: New product development; Brand adoption; Consumer loyalty

\section{Introduction}

In a highly dynamic competitive globalised market environment coupled with rapid technological changes, most manufacturing companies especially the SMEs face severe challenges on comprehension of product development times and variety. To create and sustain competitive advantage in such instances require an organisation to continuously innovate. Therefore for any firm to successfully compete in the global economy, more attention should be paid to innovation which is one of the key drivers of competitiveness.

According to Hage, innovation can be a new product, a new service, a new technology or a new administrative practice. Adler and Shenbar reveal that technological innovation capability consists of four aspects such as the ability to develop new products that meet market needs, the ability to apply appropriate process technologies to produce new products, the ability to develop and adopt new product and process technologies to fulfil future needs and the ability to respond to the technology and activities created by competitors.

However, Kahn; Stalk and Hout, confirm that to compete effectively, companies have to fulfill customers' needs better than their competitors by offering a high variety of products and that to produce a variety of products, successful firms are choosing product family and product platform design strategies to overcome the problems. Therefore, this research work examines the relationship between new product development strategies and consumer brand adoption in the SMEs manufacturing industry in Ogun State, Nigeria.

\section{Statement of Problem}

Nigerian consumers have excessive taste for foreign made goods and services. The general philosophy is if it is foreign made, then it is original and superior, but if it is Nigeria-made, then it is not original but fake and inferior.' This is often a discouragement to Nigerian investors and marketers of new products. Those of them without patience either quit the market or resort to using foreign labels on their Nigerian-made products.

Innovation processes tend to be less formalized and less well understood by small business managers. New Product Development (NPD) and innovation have been identified as strategies that can be applied to bolster a firm's competitive advantage [1], increase a firm's corporate performance and increase a firm's opportunity to grow and expand into new areas.

It is therefore imperative to understand the attributes of a firm that is successful at engaging in NPD. However, despite the numerous merits associated with NPD, very little research has been conducted that addresses NPD issues in SMEs manufacturing industry. As an engine room for development, the sector has the potential for generating employment for both rural and urban populace. Therefore, SMEs manufacturing firms become an obvious sector where the contribution of innovation and NPD to its sustainable development can be explored.

\section{Objective of the Study}

The study sets out to examine the effect of New Product Development (NPD) strategies on consumer adoption behaviour in

*Corresponding author: Kesinro OR, Department of Administration and Management, Crawford University, Igbesa, Ogun State, Nigeria, Tel: +23418134785; E-mail: romarke07@yahoo.com

Received January 12, 2018; Accepted January 31, 2018; Published February 02, 2018

Citation: Kesinro OR, Adenugba AA, Ademilua AV (2018) New Product Development and Consumer Brand Adoption in SMEs Manufacturing Industry in Ogun State Nigeria. Int J Econ Manag Sci 7: 488. doi: 10.4172/2162-6359.1000488

Copyright: @ 2018 Kesinro OR, et al. This is an open-access article distributed under the terms of the Creative Commons Attribution License, which permits unrestricted use, distribution, and reproduction in any medium, provided the original author and source are credited. 
purchase situations of SMEs products in Ogun State, Nigeria. The specific objectives are to:

I. Identify the physical attributes of SMEs products that affect buyer behaviour.

II. Examine the market pre-testing strategy that influences product adoption among SMEs customers.

III. Develop marketing planning policy that enhances competitive edge of SMEs products.

\section{Research Questions}

I. How do physical attributes of SMEs products affect buyer behaviour?

II. To what extent does market pre-testing strategy influence product adoption among SMEs customers?

III. How does marketing planning policy enhance competitive edge of SMEs product?

\section{Statement of Hypotheses}

$\mathrm{H}_{01}$ : Physical attributes of SMEs products do not have significant effect on buyer behaviour.

$\mathrm{H}_{02}$ : Market pre-testing strategy does not significantly influence product adoption in SMEs manufacturing industry.

$\mathrm{H}_{03}$ : Marketing planning policy does not significantly enhance competitive edge of SMEs products.

\section{Scope and Significance of the Study}

The study is limited to all the registered manufacturing SMEs companies in Ogun State, Nigeria. Nevertheless, to ensure the survival of manufacturing SMEs companies, a better understanding of the product development strategy/process and its practical applications to the activities and operations of entrepreneurs is desirable. Therefore, the study will further provide insights into the facts that the SMEs industry in Nigeria is still at the infancy stage of their technological development and innovation hence further enhance better marketing policy formulation by the stakeholders in the sector.

\section{Literature Review}

It has been widely observed that the practice of marketing by the SME is different from that of large organizations [2-5]; their marketing model is described as informal, unstructured spontaneous, and reactive [6]. However, stokes [7] confirmed that most SMs marketing is used for immediate needs and little attention is paid to plans and strategies and they direct their sales in order to survive.

In the same vain, Walsh and Lipinski [8] and Harris, et al. [9] also posit that for all issues outside of advertising, such as customer satisfaction measurement and improvement an deign of customer service and support, the sales function has a slightly greater influence.

Similarly Huang and Brown [10] reveal that one of the most prevalent areas in which SMEs have problems in marketing and this is largely due to their inability to adopt professional marketing practices to carry out marketing activities for the business [11].

Meanwhile, Leppard and McDonald confirmed and state that the owner-manager has significant impact on every aspect of the SMEs marketing activities. This is also corroborated by Berthon, et al. that the SME- owner manager is often responsible for the performance of functions within an organisation, such as banking, purchases, advertising and recruitment an thy often decide which marketing strategies to use because they do not have marketing managers as employers. Similarly, Moss, et al. [12] confirmed that very little is relatively known about SME marketing activities hence such functional specialisation may rarely exist.

Gilmore et al. and Reijonen are also of the view that though large organisations are often large enough to have a marketing department that permits the delineation of functions and activities unlike the SMEs with limited resources in terms of finance time and marketing knowledge. They argued further that owner-managers in SMEs tend to view marketing narrowly and marketing practitioners in this sector tend to consider marketing the same as selling or advertising.

However, traditional marketing theories fail to amount for the marketing carried out by SMEs but recognises marketing as a strategy and tactics/methods that focuses on the use of marketing mix (4P's: product, place, price, promotion); in other words, on the implementation of marketing strategy.

Nevertheless, one solution to the marketing challenges faced by SMEs is the social media that helps to overcome the challenge of limited budget, lack of expertise and positioning against larger competitors. Therefore, to gain competitive advantage, SMEs often have sought from other sources and by other means. However, the marketing philosophy that large organisations adopt cannot be generalized to that of small businesses which has different characteristics and requirements; hence small firms are moving from conventional marketing practices towards more affordable, interactive and integrated marketing.

According to Etzel et al. [13], the likelihood of achieving success with a new product, especially a really innovative product, is increased if management understands the adoption and diffusion processes for that product. Once again, organizations need to understand how respective customers behave. The adoption process is the set of successive decisions an individual person or organization make before accepting an innovation. Diffusion of a new product is the process by which an innovation spreads throughout a social system over time.

By understanding these processes, an organization can gain insight into how a product is or not accepted by prospective customers and which groups are likely to buy a product soon after it is introduced, later on, or never. This knowledge of buyer behaviour can be valuable in designing an effective marketing programme.

\section{Methodology}

The study adopts survey design to enhance a comprehensive investigation of brand physical attributes, buyer behaviour, market pre-testing strategy, product adoption, marketing planning policy and competitive edge of SMEs products in Ado-odo/Ota Local Government Area of Ogun State, Nigeria. The target population comprised 240 owner-managers and employees of manufacturing SMEs in the local government area presumed to home majority of the SMEs in Ogun State. The random and stratified sampling techniques were used to select a sample of 150 individuals. The main instrument for data collection is a structured questionnaire with two parts $\mathrm{A}$ and $\mathrm{B}$. Part A covered respondents demographic data while Part B contained items for the measurement of the variables. The questionnaire items were measured on a 6-point Likert Scale of Strongly Disagree $(S D)=1$; Disagree $(D)=2$; Fairly Disagree $(F D)=3$; Fairly Agree $(F A)=4$; Agree 
Citation: Kesinro OR, Adenugba AA, Ademilua AV (2018) New Product Development and Consumer Brand Adoption in SMEs Manufacturing Industry in Ogun State Nigeria. Int J Econ Manag Sci 7: 488. doi: 10.4172/2162-6359.1000488

Page 3 of 4

$(A)=5$; Strongly Agree $(S A)=6$. Simple Percentile and Regression Analysis statistical techniques were used to aggregate the responses and test the hypotheses.

\section{Results and Analysis}

Hypothesis 1: Physical attributes of SMEs product do not have significant effect on buyer behaviour

The model summary Table 1 provides helpful information about the regression analysis. First, the ' $R$ ' column is the correlation between the actually observed independent variables and the predicted dependent variable (i.e., predicted by the regression equation). ' $R$ square' is the square of $\mathrm{R}$ and is also known as the 'coefficient of determination'. It states the proportion (or percentage) of the (sample) variation in the dependent variable that can be attributed to the independent variable(s). Further explanation is given in Table 1.

In this study $11.1 \%$ variation in buyer behaviour. The first hypothesis which stated that" physical attributes has no impact on increase buyer behaviour was rejected at $\mathrm{R}=0.33, \mathrm{R}^{2}=0.11, \mathrm{~F}_{(1,134)}=16.556 ; \mathrm{p}<0.05$. The first hypothesis is therefore rejected. This implies that physical attributes of SMEs product has impact on increase buyer behaviour.

Hypothesis 2: There is no significant relationship between market pre-testing strategy and product adoption among SMEs customers

The model summary describes the proportion (or percentage) of the (sample) variation in the dependent variable that can be ascribed to the independent variable(s). Further explanation is given in Table 2.

In this study $11.7 \%$ variation in product adoption. The second hypothesis which stated that" there is no significant effect between market pre-testing strategy and product adoption was rejected at $\mathrm{R}=0.342, \mathrm{R}^{2}=0.117, \mathrm{~F}_{(1,134)}=17.655 ; \mathrm{p}<0.05$. The second hypothesis is therefore rejected. This implies that there is a significant effect between market pre-testing strategy among customers and adoption of product.

\begin{tabular}{|c|c|c|c|c|c|c|c|}
\hline Model & \multicolumn{2}{|c|}{$\mathbf{R}$} & \multicolumn{2}{|c|}{ R Square } & $\begin{array}{l}\text { Adjusted R } \\
\text { Square }\end{array}$ & \multicolumn{2}{|c|}{$\begin{array}{l}\text { Std. Error of the } \\
\text { Estimate }\end{array}$} \\
\hline 1 & \multicolumn{2}{|c|}{$0.333^{a}$} & \multicolumn{2}{|l|}{0.111} & 0.104 & \multicolumn{2}{|c|}{1.65514} \\
\hline \multicolumn{8}{|c|}{ ANOVA $^{b}$} \\
\hline Model & & Sur & Squares & Df & Mean Square & $\mathbf{F}$ & Sig. \\
\hline \multirow[t]{3}{*}{1} & Regression & \multicolumn{2}{|c|}{45.354} & 1 & 45.354 & 16.556 & $0.000^{\mathrm{a}}$ \\
\hline & Residual & \multicolumn{2}{|c|}{364.350} & 133 & 2.739 & & \\
\hline & Total & \multicolumn{2}{|c|}{409.704} & 134 & & & \\
\hline
\end{tabular}

apredictors: (Constant), physical attributes.

${ }^{\mathrm{b}}$ Dependent Variable: buyer behaviour.

Table 1: Model summary of Hypothesis 1.

\begin{tabular}{|c|c|c|c|c|c|c|c|c|}
\hline \multicolumn{2}{|c|}{ Model } & \multicolumn{2}{|c|}{$\mathbf{R}$} & \multicolumn{2}{|c|}{ R Square } & $\begin{array}{l}\text { Adjusted R } \\
\text { Square }\end{array}$ & \multicolumn{2}{|c|}{$\begin{array}{l}\text { Std. Error of the } \\
\text { Estimate }\end{array}$} \\
\hline \multicolumn{2}{|l|}{1} & \multicolumn{2}{|c|}{$0.342^{\mathrm{a}}$} & \multicolumn{2}{|l|}{0.117} & 0.111 & \multicolumn{2}{|c|}{1.16166} \\
\hline \multicolumn{9}{|c|}{ ANOVA $^{b}$} \\
\hline Model & & & Sur & f Squares & Df & Mean Square & $\mathbf{F}$ & Sig. \\
\hline \multirow[t]{3}{*}{1} & \multicolumn{2}{|c|}{ Regression } & \multicolumn{2}{|c|}{23.825} & 1 & 23.825 & 17.655 & $0.000^{\mathrm{a}}$ \\
\hline & \multicolumn{2}{|c|}{ Residual } & \multicolumn{2}{|c|}{179.479} & 133 & 1.349 & & \\
\hline & \multicolumn{2}{|c|}{ Total } & \multicolumn{2}{|c|}{203.304} & 134 & & & \\
\hline
\end{tabular}

aPredictors: (Constant), market pretesting strategy.

'Dependent Variable: product adoption.

Table 2: Model summary of Hypothesis 2.

\begin{tabular}{|c|c|c|c|c|c|c|c|}
\hline Model & \multicolumn{2}{|c|}{$\mathbf{R}$} & \multicolumn{2}{|c|}{ R Square } & $\begin{array}{l}\text { Adjusted R } \\
\text { Square }\end{array}$ & \multicolumn{2}{|c|}{$\begin{array}{l}\text { Std. Error of the } \\
\text { Estimate }\end{array}$} \\
\hline 1 & \multicolumn{2}{|c|}{$0.125^{a}$} & \multicolumn{2}{|l|}{0.016} & 0.008 & \multicolumn{2}{|c|}{1.25837} \\
\hline \multicolumn{8}{|c|}{ ANOVA $^{b}$} \\
\hline Model & & Sun & Squares & Df & Mean Square & $\mathbf{F}$ & Sig. \\
\hline \multirow[t]{3}{*}{1} & Regression & \multicolumn{2}{|c|}{3.367} & 1 & 3.367 & 2.126 & $0.147^{a}$ \\
\hline & Residual & \multicolumn{2}{|c|}{210.603} & 133 & 1.583 & & \\
\hline & Total & \multicolumn{2}{|c|}{213.970} & 134 & & & \\
\hline
\end{tabular}

aPredictors: (Constant), marketing planning policy.

'Dependent Variable: competitive edge.

Table 3: Model summary of Hypothesis 3.

Hypothesis 3: Marketing planning policy does not significantly enhance competitive edge of SMEs products

The model summary describes the proportion (or percentage) of the (sample) variation in the dependent variable that can be ascribed to the independent variable(s). Further explanation is given in Table 3 .

In this study $1.6 \%$ variation in improve competitive edge. The third hypothesis which stated that" marketing planning policy does significantly enhance competitive edge was retained at $\mathrm{R}=0.125$, $\mathrm{R}^{2}=0.016, \mathrm{~F}_{(1,134)}=2.126 ; \mathrm{p}<0.05$. The third hypothesis is therefore retained. This implies that there is no significant impact between marketing planning policy and improve competitive edge of SMEs products.

\section{Conclusion}

This study examines product development and SMEs performance in a bid to building relationships and engage customers. In today's information and communication driven environment, it is highly desirable that small businesses periodically review the techniques employed in product development to enhance brand image, reputation, price, longevity and expectation that guarantee consumer loyalty.

\section{References}

1. Brown SL, Eisenhardt KM (2013) Product development: Past research, present findings, and future directions. The Academy of Management Review 20: 343378.

2. Coviello N, Brodie R, Munro H (2010) An investigation of marketing practice by firm size. Journal of Business Venturing 15: 523-545.

3. Gilmore A, Carson D, Grant K (2011) SME marketing in practice. Marketing Intelligence \& Planning, 19: 6-11.

4. Hill J (2011) A multidimensional study of the key determinants of effective SME marketing activity: Part 1. International Journal of Entrepreneurial Behavious \& Research 7: 171-204.

5. Reijonen H (2010) Do all SMEs practice same kind of marketing? Journal of Small Business and Enterprise Development 17: 279-293.

6. Gilmore A, Carson D, Donnell AO, Cummins D (2010) Added value: A qualitative assessment of SME marketing. Irish Marketing Review 12: 27.

7. Stokes D (2010) Putting entrepreneurship into marketing: The Processes of Entrepreneurial Marketing. Journal of Research in Marketing \& Entrepreneurship 2: 1-16.

8. Walsh M, Lipinski $\mathrm{J}$ (2011) The role of the marketing function in small and medium sized enterprises. Journal of Small Business and Enterprise Development 16: 569-585.

9. Harris L, Rae A, Grewal S (2012) Out on the pull: How small firms are making themselves sexy with new online promotion techniques. International Journal of Technology Marketing 3: 153-168.

10. Huang X, Brown A (2013) An analysis and classification of problems in small business. International Small Business Journal 18: 73-85 
Citation: Kesinro OR, Adenugba AA, Ademilua AV (2018) New Product Development and Consumer Brand Adoption in SMEs Manufacturing Industry in Ogun State Nigeria. Int J Econ Manag Sci 7: 488. doi: 10.4172/2162-6359.1000488

Page 4 of 4

11. Berthon P, Ewing MT, Napoli J (2011) Brand management in small to mediumsized enterprises. Journal of Small Business Management 46: 27-45.

12. Moss D, Ashford R, Shani N (2013) The forgotten sector: Uncovering the role of public relations in SMEs. Journal of Communication Management 8: 197-210.

13. Etzel J, Bessant J, Pavitt KLR (2010) Managing Innovation: Integrating Technological, Market and Organizational Change, Chichester, John Wiley, USA. 